\title{
MASCULINITY IN THE METANARRATIVE OF THE GLOBAL WAR ON TERROR: SHAUNA SINGH BALDWIN'S TRANSNATIONAL CRITIQUE*
}

\author{
Belén Martín-Lucas \\ Universidad de Vigo
}

\begin{abstract}
This article offers a feminist critique of the globalized metanarrative on the so-called 'war on terror,' through an analysis -from decolonial and feminist perspectives- of Shauna Singh Baldwin's short story collection We Are not in Pakistan (2007). Focusing on the contrasting depictions of masculinity portrayed in a selection of her stories, I intend to reveal the complexities in the gendering of a metanarrative that attempts to mobilize affects of fear and revenge. In contra-diction (that is, as counter-discourse) to the dominant rhetoric of stereotypical Islamophobia, Baldwin's characters point out surprising comparisons and parallelisms across cultural differences, revealing common links and shared affectivity among characters of diverse ethnic and racial backgrounds. Vocally political, her narratives provide a transCanadian perspective on violent neoimperialism after 9/11.
\end{abstract}

KeYwords: War on terror, masculinity, neoimperialism, 9/11, Shauna Singh Baldwin.

\section{LA MASCULINIDAD EN LA METANARRATIVA DE LA GUERRA GLOBAL \\ CONTRA EL TERROR: LA CRÍTICA TRANSNACIONAL \\ DE SHAUNA SINGH BALDWIN}

\section{RESUMEN}

Este artículo ofrece una aproximación crítica a la metanarrativa globalizada de la llamada "guerra contra el terror», a través del análisis - desde perspectivas feministas y decoloniales- de la colección de relatos We Are not in Pakistan (2007) de Shauna Singh Baldwin. Centrándome en las diversas descripciones de masculinidades en una selección de relatos de esta colección, mi intención es desvelar el complejo mecanismo de género que opera en esta metanarrativa basada en los afectos del miedo y la venganza. En contra-dicción (es decir, como contradiscurso) con la retórica dominante islamofóbica, los personajes de Baldwin establecen sorprendentes comparaciones y señalan paralelismos entre distintas culturas, exponiendo vínculos comunes y afectividades compartidas entre personajes de distinto origen étnico y racial. De carácter abiertamente político, los relatos de Baldwin proporcionan una perspectiva transcanadiense sobre el neoimperialismo violento tras el 11-S.

PAlABRAS ClAVE: guerra contra el terror, masculinidad, neoimperialismo, 11-S, Shauna Singh Baldwin. 
The authors we celebrate [...] were the stubborn ones who explored forbidden themes and unspeakable conflicts. The prose that is their legacy reminds us of much we prefer to forget.

Shauna Singh Baldwin's words above refer to the social (and political) responsibility of writers to bring uncomfortable 'truths' - "forbidden themes and unspeakable conflicts" - to the spotlight. In similar spirit Stuart Hall claimed that "the work that cultural studies has to do is mobilize everything it can find in terms of intellectual resources in order to understand what keeps making the lives we live, and the societies we live in, profoundly and deeply anti-humane in their capacity to live with difference" (18; emphasis added). I find this a most urgent task in the current necropolitical (see Mbembe) context that feeds directly on the epistemologies of interested ignorance that sustain racism and sexism (Sullivan and Tuana; Medina), preventing and in fact forbidding mutual respect and solidarity across acknowledged differences. In line with Jasmin Zine and Lisa K. Taylor, I firmly believe literary analysis helps us "learn to read the world through different regimes of truth" (14). The metanarrative of the war on terror constitutes a good terrain to study competing regimes of truth and how they are institutionalized. As Mona Baker has explained:

the choice of terror rather than terrorism [...] offers a good example of the discursive work required for the successful circulation and adoption of narratives in general and meta-narratives in particular. 'Terrorism' refers to one or more incidents that involve violence, with localized and containable impact. 'Terror', on the other hand, is a state of mind, one that can rapidly spread across boundaries and encompass all in its grip. It may be that a narrative must have this type of temporal and physical breadth, as well as sense of inevitability or inescapability, to qualify as a meta- or master narrative. Terror indexes these features much better than terrorism. (45)

Undoubtedly, 9/11 has become a totemic moment often used to mark the beginning of a new era, and the foundational mythical element of a narrative of terror, as Mona Baker has argued, "aggressively sustained and promoted through a myriad of channels across the entire world, thus rapidly acquiring the status of a super-narrative that cuts across geographical and national boundaries and directly impacts the lives of every one of us, in every sector of society" (45). Literary fiction is one of those channels, and, as Juanjo Bermúdez de Castro proposes, the literary critic should ask "to what extent 9/11 fictions become an active agent of acquiescence in the process of re-writing the historical event of $9 / 11$ in concordance with biased geopolitical interests" (12). Given the high cost in lives this metanarrative produces, I believe it is necessary to offer "a direct challenge to the stories that sus-

* The research towards the writing of this article was funded by the Project "Bodies in Transit 2: Difference and Indifference" (Ref. FFI2017-84555-C2-2-P; MINECO-FEDER). 
tain these patterns [of domination]" (Baker 6). In this paper I will examine Shauna Singh Baldwin's counter-narratives to this dominant discourse in her collection of short stories We Are not in Pakistan, published in Canada in 2007, which has been described as "a study in cultural contrasts" (Reiswig n.p.).

Shauna Singh Baldwin was born in Montreal to Sikh parents, raised in India, and now living in Milwaukee (Wisconsin) ${ }^{1}$. Her works offer surprising comparisons and parallelisms across cultural differences, revealing common links and shared affectivity among characters of diverse ethnic and racial backgrounds. This is not to suggest that differences are inconsequential in her fiction; on the contrary, cultural differences often produce experiences of dislocation in hostile contexts for many of her characters. However, and despite the difficulties and misunderstandings, transcultural and transnational alliances are not only possible, but often successful. It is for this emphasis on complex interrelations across borders that she can be considered a transCanadian author, in Libe García Zarranz's understanding of the term²:

As a border concept, 'transCanadian' is thus construed relationally through an inseparable mixture of coalitions, ruptures, entanglements, tensions and alliances. [...] the realm of the transCanadian certainly becomes a porous borderland; a site of paradoxical entanglements where nation, transnation, narration, history, ecology, economy, and citizenship are rendered unstable valences, always in the process of becoming, and thus susceptible to change and transformation. (García Zarranz 9)

We Are not in Pakistan is a collection that "explores the realities of transglobal citizenship" (Sikh Heritage Museum n.p.) taking into consideration all those factors. Through the focus on individual characters in each of the stories, the narratives reveal the consequences of events and political actions on a global scale, from the Chernobyl nuclear disaster to the so-called 'Global War on Terror'. Regarding the second, the 9/11 attacks, the war in Afghanistan and Iraq, the transit bombings in London, illegal incarceration of racialized suspects and deportation of migrants are mentioned in the stories in which different characters offer clashing ideological positions. The 'war on terror' is a recurrent thread linking most of the stories and a central topic in "Fletcher", "The View from the Mountain", "We are

1 The essays collected in Baldwin's latest book to date, Reluctant Rebellions (2016), offer personal views of the author regarding her diasporic background, her feminism, her Sikh religion, and the war on terror. In this article I have avoided heavily relying on her personal views as expressed in the essays in order to foreground here the literary expression of political critique in her short stories.

${ }^{2}$ Libe García Zarranz redeploys Roy Kiyooka's original coinage of the term TransCanada in his TransCanada Letters and Pacific Rim Letters and Smaro Kamboureli's influential extension of the term in her TransCanada project, which included the TransCanada Institute at $U$ of Guelph (2007-2013) and the TransCanada Series (with Wilfrid Laurier UP); see García Zarranz pp. 8-9, and Kamboureli and Miki. 
not in Pakistan"3, "This Raghead" and "The Distance Between Us". I agree with Manjeet Ridon's assertion that this collection's "political commentary on mostly American and international matters highlights Baldwin's interest to offer new ways of understanding Canadian literature's place and influence in and beyond Canada" (n.p.). Through this strategy of kaleidoscopic perspectives, Baldwin can contest, from a transCanadian stance, different aspects of the hegemonic narrative that mobilizes, in Sara Ahmed's terms, the "affective politics of fear" (74-80) and showcase contrasting reactions in the aftermath of the $9 / 11$ attacks in diverse locations, from the angry racism of accommodated white Americans to the high vulnerability, dispossession and risk of any one suspect of being Muslim in North America. Although the stories dealing with the post $9 / 11$ context are all set in the U.S., Canada is recurrently mentioned in them, either as place of residence of an extensive South Asian diaspora in permanent contact via the phone or the internet (Baldwin, "We Are not" 149), the desired shelter they apply to for asylum ("We Are not" 150) or the source of cheaper medicines (Baldwin, "This Raghead" 191). Little references here and there to Celine Dion or to a French Canadian Grandmère help maintain in the reader's mind the cross-border connection with both English Canada and French Canada.

Most of the stories feature transnational characters who need to negotiate their place in a 'foreign' location and engage in intercultural dialogue. As one of her narrators indicates, "Context, nuances, qualifications, time frames" (Baldwin, "The Distance" 244) are crucial, and each story pays close attention to the historical trajectories that have engendered current events. Thus, allusions to the American troops in the Pacific and Mediterranean during the "Good War" (i.e. World War II; in "This Raghead"), in Nicaragua during Reagan's mandate (in "The View from the Mountain"), Korea and the first Gulf War (in "Rendezvous"), or Vietnam (in "The Distance Between Us") contextualize the contemporary battles within the longer history of American wars in foreign territories that Salah Hassan has defined as "never-ending occupations":

One can see a repeating pattern from the 1890s occupation of Puerto Rico and the Philippines to the mid-twentieth-century occupation of Germany and Japan to the early twenty-first-century occupation of Afghanistan and Iraq. In every one of these cases, the U.S. presence was ostensibly temporary, aimed at overthrowing an unjust dictatorship, yet quickly took the form of a permanent military presence. (2)

Therefore, the stories portray the 'war on terror' not as a new phenomenon suddenly erupting after 9/11 2001, but as the intensification and global expansion

3 The story that gives title to the collection focuses on female characters and for this reason it will not be part of my analysis here. I have analyzed this story in the comparative article "Transgenerational Affect and Cultural (Self)Acceptance in Two Trans-Canadian Short Stories". 
of ongoing colonization that stems from centuries ago. ${ }^{4}$ As Jasbir Puar indicates, there is in the post 9/11 context "a burgeoning ease with the notion of the United States as an empire" (1). Following Jasbir Puar, I read "9/11" in these narratives as

an event in the Deleuzian sense, privileging lines of flight, an assemblage of spatial and temporal intensities, coming together, dispersing, reconverging. The eventness of September 11 refuses the binary of watershed moment and turning point of radical change, versus intensification of more of the same, tethered between its status as a 'history-making moment' and a 'history-vanishing moment'. (xviii)

\section{NEOIMPERIALISM}

Neoimperialism is most visible in the story "The View from the Mountain", which recalls US neo-colonial interventions in Central America through the characters of a rich white American entrepreneur in the tourism industry, Ted Grand, ${ }^{5}$ and his Costa Rican staff manager, Wilson, who is the narrator. While discussing the deployment of American troops to Nicaragua ordered by Ronald Reagan to 'help his friend' the president of Costa Rica, Ted says "It's all about interests. There's no friendship, only interests" (128), an attitude that summarizes his own approach to life. Ted totally disregards the criminal corruption of the local elites: "Trust a gringo not to care that he was building on blood-soaked land" (125). As the good neoliberal capitalist that he is, Ted believes that "Destruction is an opportunity for change" (131); but only when destruction takes place somewhere else, not in his own country. When the twin towers are attacked in New York and George Bush Jr. declares he is on a crusade, Ted cheers him on, and "he was still cheering a month later when that man Bush dropped bombs on people in Afghanistan" (133); and he kept "Cheering his country's troops through the liberation of Iraq" (136). His employee Wilson, who has recently lost his wife and little daughter in a house fire, soon realizes that the deaths of Americans are much more "grievable" (see Butler) than those in Afghanistan, Iraq or Costa Rica: "norteamericanos seemed much more valuable than my Madelina or Carmen ever were. I watched so many wearing or weaving flags, but only for los Estados, though CNN said people of many countries died in the towers" (Baldwin, "The View" 133). Baldwin sharply criticizes, through Wilson's words, the interested ignorance of the hegemonic citizens of America, their myopic vision of the world and very limited know-

\footnotetext{
${ }^{4}$ British colonialism in the Indian subcontinent is explicitly mentioned in the story "The Distance Between Us".

5 Although Baldwin's collection was published many years before Donald Trump's rise to the presidency, Ted Grand resembles him so much that I wonder whether Baldwin was thinking of him while composing this fictional character.

${ }^{6}$ Although the term "norteamericanos" would include also Canadians, the sentence makes clear that in this story it refers to U.S. citizens only.
} 
ledge of their own history, as when Wilson ponders that Ted "seemed to believe no people ever, anywhere, at any time, had suffered as great a tragedy as norteamericanos. Could I blame him? All he ever read was USA Today. And the many stories he read me to improve my English featured only norteamericanos. No norteamericano, no story. As if the rest of the world was inhabited by non-persons and monkeys" (138). While Wilson wants "all those deaths to matter" (133), Ted becomes more and more infuriated and paranoid, constantly watching the tv where "retired generals debated pre-emptive strikes" (134), and violently orienting his anger towards Wilson and the rest of hotel workers in Costa Rica whom he now distrusts as potential terrorists about to use anthrax on him, even though Wilson assures him that "We are your friends, not your enemies" (134). Contrary to this view, Wilson is grateful to the friends who have helped him survive at his lowest moments: "They had no reason to help me. I said -not to Ted, because I didn't wish to offend him, but to myself- that I hoped I never thought like him" (128). Wilson's ethics of solidarity contrast with Ted's egocentric attitude. Baldwin thus makes the small-scale relations between Ted and his workers reproduce the larger political picture with the escalating of aggression between the US and its targets; in spite of their former "friendship", Ted unilaterally breaks his agreements with Wilson in the same fashion that "Ted's president had also decided he was not bound by previous agreements -larger ones, international ones. Ted was just following a bad example" (136). Ted's affective response, his misdirected anger, illustrates the mobilization of fear and its intensification into hatred that Ahmed locates at the heart of patriotic discourses of love for the nation, in a narrative of retaliation that "allowed home to be mobilised as a defence against terror" (Ahmed 74; emphasis in the original). In this xenophobic view of the homeland, the racialized migrant epitomises the 'foreign threat'. Revenge and protection of one's "homeland" is of course a dominant trope in the metanarrative of the war on terror, as we have seen in more recent responses to terrorism in Europe and the U.S.

\section{XENOPHOBIC HOMONATIONALISM}

The xenophobic discourse prevalent in dominant media representations is recurrently portrayed in all of the stories dealing with the post 9/11 context. It is most explicit in "This Raghead", as its title manifests, a story that voices the racist opinions of Larry Reilly, a 78 year-old veteran from "the Good War" (190) where he was injured by a kamikaze in the Pacific and his much admired brother was "killed in action off the coast of North Africa" (190), that is, quite far away from their homeland. While googling for information about his brother's missing ship, he finds out it had been reached when transporting explosives and bombs; he then reads about other ships with Japanese soldiers perishing or thousands injured on merchant ships in Bombay, "But those do not cause his tears" (195-96). This proves that, like Tom Grand, Larry dismisses the suffering of anyone non-American. Besides, Larry blames all evils of contemporary American society on immigrants, despite the fact that his own Irish family had come to America through Ellis Island. Larry shows 
explicit sexism, racism and xenophobia, compiling a large catalogue of derogatory labels such as "kike", "kraut", "frog", "wop", "buck" and "peacenik", among others, though he himself was once called "mick" (197); those who look Arab are, to his eyes, all terrorists and receive the pejorative epithet "ragheads"

Larry's views of immigrants reproduce conservative xenophobic discourse; he is of the opinion that "nothing is free -freedom isn't free, either" (191) though the "Goddam immigrants nowadays, they have it easy" (191; italics in the original). Moreover, it is a relief for him to think that there will not be much left in Social Security for the pension of his new cardiologist, Dr. Balkhtiar -though there won't be much for his own grandchild, either- a comment that serves as a witty measure of Baldwin's acute perception of neoliberal economic policies dismantling those social services that have been so crucial in guaranteeing a livable life, most especially for women. As Larry reflects, "Medicare is progress" (191), but it should be exclusive to 'true Americans's.

Larry expresses his patriotism as a "good American" by supporting George Bush Jr. no matter what: "we get behind our President in a time of war. The government always knows something we don't" (190). In contrast with his opinions, a resident in the compound for the elderly where he lives loudly vents her criticism of George Bush Jr.'s policies: "You line up right behind Bush along with the other sixty-two percent, sheep all of you", she shays. "You approve of him, just like the Germans got behind Hitler. And look what happened to them -they followed that madman right over the edge. I didn't vote for your smiley warmonger, nor did the majority in this country" (190), and when Larry invokes terrorism she does not hesitate to claim that "It's Bush who's the terrorist" (190) while slamming her door. Larry thinks "terrorist" again when he sees "the raghead at the adjoining clinic", Dr. Bakhtiar. Baldwin criticizes once more the role of the media in promoting this hatred discourse when she adds that "He can't not think 'terrorist' - he's been watching enough Fox and CNN to hear it every three minutes" (190),

7 Jasbir Puar records that "In the early 1900s, the term 'rag heads' was already being used in the northwestern United States to refer to turbaned men, mainly Sikhs" (274). The confusion between Sikh and Muslim turbans led to numerous cases of "mistaken identity" aggressions in the U.S. immediately after $9 / 11$, which led to campaigns on the part of Sikh communities to disassociate themselves from Muslims at a time when "The turban [was] accruing the marks of a terrorist masculinity" (Puar 175). More on this will be commented when discussing the character of Karan Singh in "The Distance between Us".

${ }^{8}$ Taxes and social services for citizens is another recurrent topic in Baldwin's stories, with frequent references to Medicare, education, pensions, roads and other public services, defending the idea of communal contribution to the welfare and the need to pay taxes to benefit everyone. This is prominent especially in "This Raghead" and "The Distance Between Us", as will be further discussed below.

9 This is also a recurrent theme in Baldwin's stories: the endless repetition of the images of destruction and death of attacks in the US and UK. In "The View from the Mountain", Ted Grand also spends hours watching the CNN and becomes paranoid, while in "The Distance Between Us", Karan comments on the covering of the bombings in London and the saturation of repeated images of the dead and the "smug photos of suspected Muslim men" (229), adding that "[i]n 2001, one of his 
and he refers to the medical assistant as "the terrorist's secretary". In the paranoid way of the post 9/11 context he fears the doctor's touch because "the raghead could be gay" (192; italics in the original), thus reproducing the stereotype of the homosexual terrorist analyzed at length by Jasbir Puar in Terrorist Assemblages: Homonationalism in Queer Times (2007), where she affirms that queerness is endowed upon bodies suspect of terrorism and "a generalized rubric applied to populations" in such a way that the terrorist "is always already pathologically queer" (169). In his paranoia, Larry thinks that "Maybe the raghead kills Americans slowly, turning up the heartbeat, turning up the pace, till millions of hearts drop dead from exhaustion" (192). At the end of the story, Larry in fact suffers a heart attack and he is first attended by a Black security guard in his building who, like Larry's own brother, has just lost a brother blown in Baghdad; this parallelism shocks Larry, and "Faces collide and combine in his mind" (197) when he becomes aware of his unexpected bonding with "the coloured guy" (197). As he is being carried to an ambulance, he notices that Dr. Bakhtiar's "warm brown hands buttress Larry's cold clammy hand. Right this minute Larry needs this raghead's skills, his experience and all his compassion. So this time, Larry doesn't pull away" (198; emphasis added). The narrative thus closes presenting the white American bigot in need for help from his 'enemy' and becoming a bit more humane through interracial contact, both physical and emotional, with both men.

Homosexuality is also approached explicitly in "Fletcher", a narrative focalized, in posthumanist fashion, through the eyes and opinions of a Lahsa Apso with that name who favours "cross-breed loving" (106). In this story two American men confront their views over the war on terror: Martin, a Jewish and gay New Yorker, versus Tim, a prototypical pro-Bush WASP from one of "the fly-over states" (107). Like Ted and Larry in the previous stories, Tim reproduces the discourse of dominant white masculinism, with offensive generalizing comments about "the Ayatollah types [...] those Moslem fundamentalists" (112). The conversation between the two men clearly shows their polarized positions; I will reproduce it here as a selfexplanatory example of the polemicist spirit in Baldwin's counter-discourse:

Martin says to Tim, "Makes you wonder what we've been doing to cause so much hatred, doesn't it?”

"Oh, we haven't done anything they wouldn't do to the tenth power in our position," says Tim bristling. "If the ragheads were on top, you think they wouldn't blow up more than the World Trade Center? They think they're going straight to heaven when they blow themselves up. I say lock 'em all up and sterilize them." Tim expects Martin to nod in agreement - he thinks everyone agrees with him. [...] "Lock who up?" says Martin, leaning forward. "All Arab Americans?" [...]

"Nah, just the foreigners," says Tim.

colleagues said the scene of the planes and the twin towers was replayed so often that her five-yearold thought all the planes were falling from the skies and crashing into buildings" (229). 
"That's how the Nazis began, with just the foreign Jews. Gradually, they turned fear to hatred." ${ }^{10}(112-13)$

Martin's response, "they turned fear to hatred", points out the mobilization of affects regarding the love for the nation that Sara Ahmed has analyzed in detail in The Cultural Politics of Emotion (2004), where she exposes how love for the nation is expressed through hate towards perceived foreigners:

Such narratives work by generating a subject that is endangered by imagined others whose proximity threatens not only to take something away from the subject (jobs, security, wealth), but to take the place of the subject. The presence of this other is imagined as a threat to the object of love. This narrative involves a rewriting of history, in which the labour of others (migrants, slaves) is concealed in a fantasy that it is the white subject who 'built this land'. [...] The narrative hence suggests that it is love for the nation that makes the white Aryans feel hate towards others who, in 'taking away' the nation, are taking away their history as well as their future. (43)

Martin furthers points to this mechanism of hate when he responds to Tim's "anyone who can't speak English should be sent home" with "You sound like you hate lots of people who are already at home" (Baldwin, "Fletcher" 113). Intolerance is thus reassigned by Baldwin to the bigot white supremacist, in contradiction of the liberal gesture studied by Wendy Brown which, in the rhetoric of justification of the war on terror, has appropriated tolerance as a quality of the civilized West versus the intolerant barbaric fundamentalist Oriental other (Brown 6-7): "in the aftermath of September 11, political rhetorics of Islam, nationalism, fundamentalism, culture and civilization have reframed even domestic discourses of tolerance -the enemy of tolerance is now the weaponized radical Islamicist state or terror cell rather than the neighbourhood bigot" (6). In "Fletcher", the intolerance of bigot Tim is contraposed also to the more classic liberal tolerance of Colette, which she attributes to her being of French Canadian descent ${ }^{11}$ : "Accepting gayness is so New York or California, she might forget where she is -in a subdivision in the heart of the Bible

${ }^{10}$ The comparison between Islamophobic prosecution in the context of the war on terror and the Nazi genocide is, as we can see, recurrent in the collection, and has been commented upon by Baldwin in her essay "Ruthless Terrorist or Valiant Spy" in relation to her novel The Tiger Claw (2004), set in occupied France during the Second World War: "Just as in the book, where Noor searches for her beloved Armand Rivkin, who has been rounded up as a terrorist and locked away in a camp, some woman in Afghanistan waits and prays for news from Guantánamo Bay about her husband or lover. Just as Noor was trying to send her Armand a message in 1943, some woman is trying to reach her 'enemy combatant' husband through the International Red Cross, hoping he is alive after two years in prison, hoping he has not been tortured" (Reluctant Rebellions n.p.).

${ }^{11}$ Colette's self-complacency in this comparison proves she is not that much more tolerant than Tim; Baldwin treats her with ironic -humorous- benevolence, portraying her as a neoliberal postfeminist obsessed with 'catching' Tim as a husband: "Colette says some women still need men. Or maybe they just need husbands, unlike Gloria Steinem's generation. Perhaps, genetic mutation being what it is, there are by now fish who need bicycles and Lhasas who need snowboards" (103). 
belt. It's her French-Canadian side; Tim would have shown this man the door right away" (107; emphasis added).

Tim's racist tirades reproduce the vindictive discourse that served to endorse the Patriot Act and its suspension of the civil rights of suspects of terrorism. In the face of such intolerance of difference, Martin concludes "Sometimes I think we humans deserve to be annihilated [...] for what we do to one another for profit or love or religion" (114).

\section{WRONGFUL SUSPICIONS}

The final story, "The Distance between Us", provides the perspective of the suspect terrorist figure to depict the effects of the new policies on the lives of racialized migrants in the US, vulnerable to deportation or incarceration in Guantánamo, sent into oblivion without further notice to their relatives. The story narrates the degradation in the life of Karan Singh, a Sikh university professor in Santa Barbara who had secured a green card through a 'marriage of convenience' to an American woman, Rita, so that he could afford paying his $\mathrm{PhD}$ fees. Twenty-three years after their separation, an unknown of daughter suddenly comes to visit him, what she sardonically describes as her own "Shock and Awe bombshell" (233).

The story registers the many aggressions against anyone resembling a Muslim in the US, with references to Guantánamo prisoners, Sikh men being beaten, deportation, monitoring of emails by CIA and FBI, professors in Middle Eastern Studies being denounced ${ }^{12}$. Karan, now "the only faculty member with turban and beard" (227) at University of California Santa Barbara, has applied for tenure and citizenship, and both are compromised in this paranoid context, when his Dean has asked him to register with Homeland Security with the suspicious question, "You don't have anything to worry about -right?" (224). Like Ted, Larry and Tim in the preceding stories, the dean's is the xenophobic "voice of America": "The dean, a supposedly educated man, seemed to believe that the constitution was suspended and would be for the foreseeable future. He didn't think it could protect foreign-born people or non-citizens in a time of war. National origin, he said, that was the key" (239; emphasis added). It is highly ironic that the "citizenship" that is so much praised by the White American characters and guarded by the vigilant INS is in fact one more expenditure that can be bought by the 2,500 dollars Karan pays to his wife Rita. Still, racial difference and the visible marks of his Sikh religion -the turban and the beard- are insurmountable obstacles to being considered an American, as Puar denounces: "Despite the taxonomies of the turban, its specific

12 In her essay "Writing in a Time of Terrorism", Baldwin explains that "Bill HR3077 of 2003 affects academic writing, as it sets up an 'advisory' or 'monitoring' body on Area Studies departments that receive federal funding. It would make it illegal to criticize the government and allows the government to decide whose voices are mainstream" (Reluctant Rebellions n.p.). 
regional and locational genealogies, its placement in time and space, its singularity and its multiplicity, the turban-as-monolith profoundly troubles and disturbs American national imaginaries and their attendant notions of security" (175). Karan envies his daughter's freedom, and how she simply takes it for granted: "You are born here, he wants to tell her. You cannot be deported. You have light skin; you will never understand" (Baldwin, "The Distance" 241; italics in the original). But she does understand, and she replies reminding Karan of the colonial foundations of the US with the historical fact that "if you are not Native American, you're descended from immigrants too" (248).

Karan is the target of numerous hate crimes: his house is often vandalized and he is repeatedly insulted in public spaces, being mistaken for a "Fucking Ay-rab" (234) and shouted the classic "Go home, Bin Laden"13 (229), to which he politely replies "I am home, mister", a trite ignorant insult that Baldwin mocks with the narratorial comment "Karan is much better looking [than Osama Bin Laden] -plenty women would agree" (230). When his new house is burnt down by his adolescent neighbour, it is Karan who is charged with criminal assault for having jumped on the boy and smeared mud on his face, which opens the gate of deportation or prison. Even at his lowest moment he still thinks of the slum inhabitants seeing their homes bulldozed, the villagers displaced when a new dam is built, of tsunami survivors, or the masses of people killed in previous wars. His thoughts are with the dispossessed, and not of "Self-interest, the American creed" (269). As he explains to his daughter Uma, "If not my turban, people like that kid will find other things to hate or envy. This is about economics and power. The rest -just cover" (269). Karan's ambivalent participation in "American" society is directly put in relation to the war; he wants to be a good citizen, but the case becomes more difficult every day since "fear has replaced love"14 (239): "He used to have his taxes completed by January, when paying them was a privilege, the price he paid for smooth roads, clean water, future Social Security. But he's been procrastinating since he began paying for two wars, torture and detention. Still, he pays. Because he's one of the good kind, the hard-working White collar immigrant" (236). He knows "he should be so grateful

13 Although Amy Reiswig has written in a review that "While white, middle-class conservativism is a valid view to excavate, lines like 'Go home, Bin Laden' or 'Bastards! Nuke the lot' simply feel clichéd, which mars Baldwin's artistry” (n.p.), these scenes of abuse are no exaggeration and simply reproduce common experiences among Sikh men in North America, as Puar registers: "Since September 11, 2001, Sikh men wearing turbans, mistaken for kin of Osama bin Laden, have been disproportionately affected by backlash racist hate crimes. Let us ponder for a moment the span of violence: verbal harassment (being called 'bin Laden', 'son of Bin Laden, 'Osama'”, especially on the phone and while driving" (178-79). For a more exhaustive list of racist wrongs against Sikh men see Puar's chapter "the turban is not a hat" in Terrorist Assemblages, pp. 166-202 and Baldwin's Reluctant Rebellions.

${ }_{14}$ Baldwin is keen to expose the economic roots of wars, usually hidden under layers of cultural, religious and ethnic clash narratives; in relation to the riots massacring Sikhs in India in the 1980s, she has Karan "explore the economic rationale underlying the pogroms" (We Are not 244) devised by Indira Gandhi's government. 
to live in the land of the free and the home of the brave. But there were bad times... Some very bad times after 9/11" (238). For instance, his five-day detention in solitary confinement in Sacramento, where he is "interrogated" and harassed without an apology: "This happened in God Blessed America. It happened to him" (239). After this experience he realizes that no one will come to his help, no one will claim a relationship with a suspect; and also, that the cases are so numerous that he cannot find a civil rights attorney because they are "swamped with Guantánamo cases or simply unwilling to take up his" (239). In this hostile context only Uma, his newly discovered daughter, comes to bring him a different attitude, and when he feels "the solidness of her arms closing around his waist" in their goodbye, he asks her to phone him so that "the distance between us won't seem so much" (270); this is a final scene that once more reasserts the possibility of bonding across racial, cultural, and generational distances.

\section{CONCLUSIONS}

As I hope my analysis has helped to reveal, Baldwin's narratives propose an ethics of transnational solidarity to counter hegemonic racist and sexist capitalist tenets sustaining militarized globalization. The metanarrative of the war on terror exploits 'freedom and democracy' as fundamental pillars of its civilizing mission, but the actual war of terror has in fact restrained, when not simply cancelled, the freedom and democratic rights of citizens; it has also appealed to feminist ideals, while in fact reaffirming and reinforcing classic ideals of aggressive and violent masculinity dependent upon the symbolic emasculation -in the form, for instance, of deturbaning of those targeted as 'barbaric others' (Puar 179).

During Donald Trump's presidency the loss of civilian lives in Iraq, Afghanistan and Syria has skyrocketed, proving, in words of Glenn Greenwald, that "Trump's War on Terror Has Quickly Become as Barbaric and Savage as He Promised" (n.p.; emphasis added). And he is not alone in the crusade; recent bombing raids over Syria involving European, Asian and American forces continue to demonstrate the global character of this ongoing conflict and the nil value given to the lives of most civilians, refugees and those forcefully displaced. In the face of such blatant despisal for the lives of those who suffer the consequences of our old and new colonialisms, the direct challenge to the hegemonic narrative of the war on terror continues to be an urgent task. Baldwin engages with this difficult critique from a transCanadian complex perspective that allows her to explore diverse and contrasting political positions. As Ridon emphasizes, "Baldwin's perspective of here now is global, but the diversity also highlights that the characters and their lives are interconnected by their humanity and the desire for connection, particularly when struggling against displacement and isolation" (n.p.). In my opinion, "planetary" would be a more appropriate term than "global" to define Baldwin's perspective, given her ethical stance and her emphasis on cosmopolitan interrelatedness (see Moraru) in the stories. Despite the terrible events and personal conflicts these characters confront, hope is still a ringing note in the collection, showing Baldwin's firm belief in 
cross-cultural resistance and solidarity, as expressed in her essay "Ruthless Terrorist or Valiant Spy?":

each of us is presented a choice at every moment, to acquiesce or resist, to be faithful to the values of love and justice or to compromise our principles for the sake of comfort and advancement. [...] Reading about amazing acts of resistance, I learned that even in a total war against empathy like the one waged in Nazi Germany, not everyone succumbed. The Nazis could not outlaw kindness, concern, and compassion. Activists, concerned Americans, writers, and others who protest show me the same is true in our times. (Reluctant Rebellions n.p.)

It has been my intention with this article to contribute to the academic activism demanded by Stuart Hall in order to learn to live with difference which, he adds, is the message of cultural studies, "a message for academics and intellectuals but, fortunately, for many other people as well" (18); by bringing to the fore Baldwin's contra-discourse of the hegemonic metanarrative of 'the global war on terror' I wish to value her contribution as a transCanadian literary author, but also to invite readers and critics to explore other forms of cultural counterdiscourse, because we also have a choice "to acquiesce or resist" the cultural narratives of our times.

Reviews sent to author: 15 December 2018

Revised paper accepted for publication: 22 December 2018 


\section{WORKS CITED}

Ahmed, Sara. The Cultural Politics of Emotion. New York: Routledge, 2004. Print.

Baker, Mona. Translation and Conflict. A Narrative Account. London and New York: Routledge, 2006. Print.

Baldwin, Shauna Singh. The Tiger Claw. Toronto: Knopf Canada, 2004. Print.

Baldwin, Shauna Singh. "Fletcher". We Are not in Pakistan. Fredericton, NB: Goose Lane, 2007. 97-124. Print.

Baldwin, Shauna Singh. "The Distance between Us". We Are not in Pakistan. Fredericton, NB: Goose Lane, 2007. 217-271. Print.

Baldwin, Shauna Singh. "The View from the Mountain”. We Are not in Pakistan. Fredericton, NB: Goose Lane, 2007. 125-140. Print.

Baldwin, Shauna Singh. "This Raghead”. We Are not in Pakistan. Fredericton, NB: Goose Lane, 2007. 187-198. Print.

Baldw in, Shauna Singh. "We Are not in Pakistan”. We Are not in Pakistan. Fredericton, NB: Goose Lane, 2007. 141-167. Print.

Baldwin, Shauna Singh. Reluctant Rebellions. New and Selected Nonfiction. Abbotsford, BC: Centre for Indo-Canadian Studies University of the Fraser Valley \& Vichar, 2016. Kindle.

Bermúdez de Castro, Juanjo. Rewriting Terror: The 9/11 Terrorists in American Fiction. Alcalá de Henares: Servicio de Publicaciones de la Universidad de Alcalá de Henares, 2012. Print.

Brown, Wendy. Regulating Aversion. Tolerance in the Age of Identity and Empire. Princeton (NJ): Princeton UP, 2006. Print.

Butler, Judith. "Sexual Politics, Torture, and Secular Time". The British Journal of Sociology 59.1 (2008): 1-23. 12 April 2018. Web <https://onlinelibrary.wiley.com/doi/epdf/10.111 $1 / \mathrm{j} .1468-4446.2007 .00176 . \mathrm{x}>$.

García Zarranz, Libe. TransCanadian Feminist Fictions: New Cross-Border Ethics. Montreal and Kingston: McGill Queen's UP, 2017. Print.

Greenwald, Glenn. "Trump's War on Terror Has Quickly Become as Barbaric and Savage as He Promised”. The Intercept, 26 March 2017. 10 May 2018. Web <https://theintercept. com/2017/03/26/trumps-war-on-terror-has-quickly-become-as-barbaric-and-savage-ashe-promised/>.

Hall, Stuart. "Race, Culture, and Communications. Looking backward and forward at Cultural Studies". Rethinking Gramsci. Ed. Marcus E. Green. London and New York: Routledge, 2011.11-18. Print.

Hassan, Salah D. “Never-Ending Occupation”. CR: The New Centennial Review, 8.1 (2008): 1-17. 28 April 2018. Web <https://muse.jhu.edu/article/246536/pdf>.

Kamboureli, Smaro. Preface. Trans.Can.Lit. Resituating the Study of Canadian Literature. Ed. Smaro Kamboureli and Roy Miki. Waterloo, ON: Wilfrid Laurier UP, 2007. vii-xviii. Print.

Kiyooka, Roy. TransCanada Letters. 1975. Ed. Smaro Kamboureli. Edmonton: NeWest Press, 2005. Print. 
Martín-Lucas, Belén. "Transgenerational Affect and Cultural (Self)Acceptance in Two Trans-Canadian Short Stories". Atlantis: Journal of the Spanish Association for Anglo-American Studies, 40.1 (2018): 193-211. Web <http://doi.org/10.28914/Atlantis-2018-40.1.10>.

Мвемвe, Achille. “Necropolitics”. Trans. Libby Meintje. Public Culture 15.1 (2003): 11-40. 23 April 2018. Web <https://read.dukeupress.edu/public-culture/article/15/1/11/31714/Necropolitics>.

Medina, José. The Epistemology of Resistance: Gender and Racial Oppression, Epistemic Injustice, and Resistant Imaginations. Oxford and New York: Oxford UP, 2013. Print.

Moraru, Christian. “'World,' 'Globe,' 'Planet': Comparative Literature, Planetary Studies, and Cultural Debt after the Global Turn". The 2014-2015 Report on the State of the Discipline of Comparative Literature. American Comparative Literature Association, 2015. 10 May 2018. Web <https://stateofthediscipline.acla.org/entry/\%E2\%80\%9Cworld\%E2\%80\%9D\%E2\%80\%9Cglobe $\%$ E2\%80\%9D-\%E2\%80\%9Cplanet $\%$ E2\%80\%9D-comparative-literature-planetary-studies-and-cultural-debt-after>.

Puar, Jasbir. Terrorist Assemblages. Homonationalism in Queer Times. Durham, NC: Duke UP, 2007. Print.

ReIswig, Amy. Review of We Are Not in Pakistan. Quill and Quire, 2007. 10 May 2018. Web <https:// quillandquire.com/review/we-are-not-in-pakistan/>.

Ridon, Manjeet. "Re-assessing Ideas of the Transnational in Shauna Singh Baldwin's We are not in Pakistan (2007)". Conference paper. BACS Literature Group. Where is Here Now. June 2011. 28 April 2018. Web <https://sites.google.com/a/canadian-studies.org/bacsliteraturegroup/programme/manjeet-ridon>

Sikh Heritage Museum of Canada. "Shauna Singh Baldwin”. 12 April 2018. Web < http://shmc. ca/work/shauna-singh-baldwin/>.

Sullivan, Shannon and Nancy Tuana, eds. Race and Epistemologies of Ignorance. New York: State University of New York Press, 2007. Print.

Zine, Jasmin and Lisa K. TAYLOR "Introduction. The Contested Imaginaries of Reading Muslim Women and Muslim Women Reading Back." Muslim Women, Transnational Feminism and the Ethics of Pedagogy. Contested Imaginaries in Post-9/11 Cultural Practice. Ed. Jasmin Zine and Lisa K. Taylor. New York and London: Routledge, 2014. 1-22. Print. 
